\title{
PROFIL KEMAMPUAN BERINKUIRI SISWA SMA PADA TOPIK PENGARUH PERUBAHAN SUHU TERHADAP SISTEM KESETIMBANGAN KIMIA
}

\author{
Yuli Handayanti ${ }^{1}$, Wahyu Sopandi ${ }^{1}$, Asep Kadarohman ${ }^{1}$ \\ 1 Pendidikan Kimia Fakultas Pendidikan Matematika dan Ilmu Pengetahuan Alam \\ Universitas Pendidikan Indonesia, Jl. Setiabudhi No. 229 Bandung 40154 Indonesia \\ e-mail: handayantiyuli@gmail.com
}

\begin{abstract}
ABSTRAK
Penelitian ini bertujuan untuk memetakan kemampuan berinkuiri siswa SMA pada topik pengaruh perubahan suhu terhadap sistem kesetimbangan kimia. Metode yang digunakan adalah metode penelitian deskriptif, dengan subjek siswa kelas XI sebanyak 212 orang yang berasal dari 4 SMA di kota Bandung dan 1 SMA di kabupaten Bandung Barat. Pengumpulan data dilakukan dengan menggunakan instrumen penelitian utama berupa tes dan instrumen pendukung berupa pedoman wawancara dan studi dokumentasi. Hasil penelitiannya menunjukkan bahwa kemampuan berinkuiri siswa SMA secara keseluruhan pada topik pengaruh perubahan suhu terhadap sistem kesetimbangan kimia diantaranya aspek mengajukan pertanyaan $69,34 \%$, aspek merumuskan hipotesis $58,02 \%$, aspek merancang percobaan $32,08 \%$, aspek mengumpulkan data $75,94 \%$, aspek interpretasi data $75,47 \%$ dan aspek menyimpulkan $68,40 \%$.
\end{abstract}

Kata kunci: inkuiri, kesetimbangan kimia, suhu.

\begin{abstract}
The research aims to knowing the ability of inquiry's senior high school students on the topic the effect of temperature on the chemical equilibrium system. The method used is descriptive research method, involving 212 students of class XI who come from 4 high schools from the center of Bandung city and 1 high school from West Bandung. The data was collected by using primary research instrument was tests, and supporting instruments were interview guides and documentation of study. Research results showed that the aspect of asking questions is 69,34\%, the aspect of formulating hypotheses is $58,02 \%$, the aspect of designing experiment is $32,08 \%$, aspect of collecting data is $75,94 \%$, the aspect of interpretation data is $75,47 \%$ and the aspect of concludes is $68,40 \%$.
\end{abstract}

Keywords: inquiry, chemical equilibrium, temparature.

DOI: http://dx.doi.org/10.15575/jta.v1i2.1232 


\section{Pendahuluan}

Ilmu Pengetahuan Alam (IPA) adalah salah satu disiplin ilmu yang memiliki dan menunjukkan karakteristik tertentu yang berbeda dengan bidang atau disiplin ilmu lainnya. Carin (Amien, 1987) menyatakan IPA sebagai suatu kumpulan pengetahuan yang tersusun secara sistematik, yang di dalam penggunaannya secara umum terbatas pada gejala-gejala alam. Oleh karena itu, IPA merupakan suatu proses penemuan (science as process) di samping sebagai suatu penguasaan kumpulan pengetahuan (science as products) yang berupa fakta-fakta, konsep-konsep, atau prinsip-prinsip.

Berdasarkan hal tersebut maka karakteristik pembelajaran IPA tidak hanya mengajarkan mengenai kumpulan pengetahuan, tetapi mengajarkan juga bagaimana pengetahuan tersebut ditemukan. Hal itu sejalan dengan salah satu tujuan pembelajaran IPA yang terdapat dalam Standar Isi Mata Pelajaran IPA (BSNP, 2006), yaitu melakukan inkuiri ilmiah untuk menumbuhkan keterampilan berpikir, bersikap dan bertindak ilmiah serta berkomunikasi.

Selanjutnya IPA itu sendiri terdiri dari berbagai rumpun ilmu di dalamnya. Salah satunya adalah kimia yang mengkhususkan bahasannya pada struktur dan komposisi zat, perubahan, dan energi yang menyertai perubahan tersebut. Dengan demikian, pembelajaran yang dilakukan dalam kimia harus mencerminkan karakteristik dari pembelajaran IPA yang meliputi aspek pembelajaran produk dan proses. Selain itu, harus pula memenuhi karakteristik dari pembelajaran kimia itu sendiri yang meliputi aspek makroskopik, submikroskopik, dan simbolik.

Berkenaan dengan hal tersebut, maka dalam praktiknya pembelajaran kimia harus menggunakan suatu model pembelajaran yang mampu menciptakan situasi bagi peserta didik untuk menggali dan menemukan konsep sendiri. Salah satu model pembelajaran yang dapat mencakup pengembangan aspek pembelajaran produk dan proses adalah model pembelajaran inkuiri, sehingga dengan model pembelajaran tersebut kemampuan berinkuiri siswa dalam belajar kimia diharapkan dapat tumbuh dan berkembang.

Berdasarkan uraian di atas, terlihat bahwa kemampuan berinkuiri siswa ini penting untuk dikembangkan. Akan tetapi, sampai saat ini belum ada penelitian yang berusaha untuk memetakan kemampuan berinkuiri siswa SMA dalam mata pelajaran kimia. Informasi yang diperoleh tentang kemampuan berinkuiri siswa SMA tersebut dinilai sangat penting sebagai bahan masukan dan evaluasi terhadap pembelajaran yang dilakukan guru kimia di kelas.

Penelitian yang telah dilakukan selama ini hanya meneliti tentang inkuiri dan hubungannya dengan peningkatan pemahaman konsep siswa, salah satunya seperti yang dituliskan oleh Hamdu (2007) dalam tesisnya bahwa penerapan model pembelajaran inkuiri dapat meningkatkan penguasaan konsep siswa secara umum dan mengembangkan kemampuan dasar bekerja ilmiah serta sikap siswa.

Selanjutnya berdasarkan standar isi mata pelajaran kimia SMA/MA terdapat sejumlah topik yang harus dipelajari siswa selama belajar kimia di Sekolah Menengah Atas/Madrasah Aliyah, salah satunya yaitu materi pokok kesetimbangan kimia. Materi pokok kesetimbangan kimia tersebut memungkinkan dipilih sebagai topik penelitian yang dapat digunakan untuk melihat kemampuan siswa SMA dalam berinkuiri, sebab pada dasarnya semua materi kimia ditemukan oleh ilmuwan melalui suatu proses berinkuiri. Selain itu, sebuah penelitian tesis dari Akhyani (2008) yang berjudul "Model Pembelajaran Kesetimbangan Kimia Berbasis Inkuri Laboratorium untuk Meningkatkan Penguasaan Konsep dan Keterampilan Berpikir Kritis Siswa SMA" menunjukkan bahwa materi kesetimbangan kimia tersebut dapat diinkuirikan atau diajarkan menggunakan model inkuiri. Namun demikian, sampai saat ini belum ditemukan adanya penelitian yang mencoba 
mengungkap kemampuan berinkuiri siswa SMA pada materi tersebut.

Oleh karena itu, perlu dilakukan penelitian sejauh mana pembelajaran kimia saat ini dapat mengembangkan kemampuan berinkuiri siswa SMA pada materi pokok kesetimbangan kimia tersebut. Akan tetapi, materi yang diteliti pada penelitian ini dibatasi pada topik pengaruh perubahan suhu terhadap sistem kesetimbangan kimia. Oleh sebab itu, penelitian ini berjudul "Profil Kemampuan Berinkuiri Siswa SMA pada Topik Pengaruh Perubahan Suhu terhadap Sistem Kesetimbangan Kimia".

Tujuan dari penelitian ini adalah untuk memetakan kemampuan berinkuiri siswa SMA pada topik pengaruh perubahan suhu terhadap sistem kesetimbangan kimia.

Inkuiri sendiri berasal dari bahasa Inggris yaitu inquiry yang berarti pertanyaan atau penyelidikan. Exline (2004) mendefinisikan inkuiri sebagai "Inquiry is defined as a seeking for truth, information, or knowledgeseeking information by questioning". Hal tersebut menunjukkan bahwa inkuiri didefinisikan sebagai pencarian kebenaran, informasi, atau pencarian informasipengetahuan melalui pertanyaan.

Adapun model pembelajaran inkuiri adalah suatu pembelajaran untuk mencari kebenaran, informasi atau pengetahuan dengan cara mengajukan sejumlah pertanyaan (Exline, 2004). Model pembelajaran tersebut berupaya menanamkan dasar-dasar berpikir ilmiah pada diri siswa, sehingga dalam proses pembelajaran ini siswa lebih banyak belajar sendiri dan mengembangkan kreativitas dalam memecahkan masalah. Siswa benarbenar ditempatkan sebagai subjek yang belajar. Peranan guru dalam pembelajaran dengan model inkuiri adalah sebagai pembimbing dan fasilitator. Lebih lanjut, Sagala (Tn. 2008) menyatakan bahwa bimbingan dan pengawasan guru masih diperlukan, tetapi intervensi terhadap kegiatan siswa dalam pemecahan masalah harus dikurangi.
Salah satu prinsip utama inkuiri yaitu siswa dapat mengkonstruksi sendiri pemahamannya dengan melakukan aktivitas aktif dalam pembelajarannya (Rustaman, 2004). Untuk itu, pada dasarnya inkuri memiliki tahapan yang mengandung aspekaspek tertentu yang khas. Banyak pendapat dari ahli mengenai tahapan berinkuiri, namun secara umum penelitian ini fokus pada enam tahap inkuiri. Tahapan berinkuiri tersebut adalah mengajukan pertanyaan, merumuskan hipotesis, merancang percobaan, mengumpulkan data, interpretasi data, dan menyimpulkan. Keenam tahapan tersebut dianggap sebagai suatu proses berinkuiri yang lengkap dan cukup untuk menemukan jawaban terhadap masalah yang diinkuirikan. Tahap berinkuiri di atas, ini, mirip dengan tahapan berinkuiri yang dikemukakan oleh Eggen dan Kauchak (Trianto, 2009).

Banyak penelitian sebelumnya yang relevan dengan penelitian yang dilakukan, baik dari tinjauan masalah yang diteliti (tentang inkuiri) maupun materi pokok/topik yang dipilih (kesetimbangan kimia). Joyce et al. (2000) menyatakan bahwa penerapan model pembelajaran inkuiri dapat meningkatkan keterampilan proses ilmiah dan strategi berinkuiri siswa. Kuhne (Alberta, 2004) menyatakan bahwa pembelajaran berdasarkan inkuiri terhadap para siswa dapat membantu mereka menjadi lebih kreatif, lebih berpikir positif dan lebih percaya diri. Penelitian dari GLEF (Alberta, 2004) juga menyebutkan bahwa pembelajaran berdasarkan inkuiri meningkatkan prestasi siswa. Hidayat (2004) mengungkapkan bahwa dengan model pembelajaran inkuiri terbimbing menyebabkan terjadinya peningkatan pada pemahaman konsep, pengembangan aspek afektif dan psikomotor, serta pembelajaran berpusat pada siswa. Adapun kelemahan model tersebut adalah waktu yang dibutuhkan relatif lama terutama tahap diskusi. Menurut Sidharta (2005), selain peningkatan pemahaman konsep siswa, model pembelajaran asam basa berbasis inkuiri laboratorium dapat meningkatkan keterampilan berpikir kreatif dan keterampilan proses sains siswa. Susanti 
(2005) mengungkapkan bahwa melalui implementasi pembelajaran inkuiri, secara keseluruhan siswa mengalami peningkatan penguasaan konsep. Dalam skripsi yang berjudul analisis kesulitan siswa SMA kelas 2 pada topik kesetimbangan kimia melalui skema pemecahan masalah, Lugina (2005) menyebutkan bahwa setiap kelompok siswa belum mempunyai kemampuan untuk memahami konsep kesetimbangan kimia secara utuh.

Dari beberapa studi pendahuluan tersebut, dapat disimpulkan bahwa selama ini sudah banyak dilakukan penelitian tentang inkuiri dan hubungannya dengan peningkatan pemahaman konsep siswa (aspek kognitif), baik yang dilakukan di dalam maupun di luar negeri. Akan tetapi, sejauh ini belum ditemukan penelitian yang mencoba memetakan kemampuan berinkuiri siswa dalam mata pelajaran kimia seperti pada materi kesetimbangan kimia, khususnya pada topik penelitian yang dipilih yaitu pengaruh perubahan suhu terhadap sistem kesetimbangan kimia.

\section{Metode Penelitian}

Metode yang digunakan dalam penelitian ini adalah metode penelitian deskriptif. Penelitian deskriptif (descriptive research) ditujukan untuk mendeskripsikan suatu keadaan atau fenomena-fenomena apa adanya. Penelitian deskriptif tidak memberikan perlakuan, manipulasi atau pengubahan pada variabel-variabel bebas, tetapi menggambarkan suatu kondisi apa adanya (Sukmadinata, 2007). Adapun yang dideskripsikan pada penelitian ini adalah kemampuan berinkuiri siswa SMA pada topik pengaruh perubahan suhu terhadap sistem kesetimbangan kimia.
Subjek dalam penelitian ini adalah siswa SMA kelas XI yang telah mempelajari materi kesetimbangan kimia dari 4 SMA di kota Bandung dan 1 SMA di kabupaten Bandung Barat. Pemilihan subjek tersebut bukan dimaksudkan untuk melakukan generalisasi terhadap SMA yang ada di Bandung, namun penelitian ini hanya sebagai petunjuk awal kecenderungan kemampuan berinkuiri siswa SMA untuk setiap SMA tersebut. Jumlah subjek penelitian seluruhnya adalah 212 orang, terdiri dari 88 orang siswa laki-laki dan 124 orang siswa perempuan.

Instrumen penelitian yang digunakan dibagi menjadi dua kategori, yaitu instrumen utama dan instrumen pendukung. Instrumen utama berapa tes bentuk pilihan ganda terdiri dari 6 soal dengan 4 pilihan jawaban. Tiap soal mewakili aspek berinkuiri siswa, sehingga jawaban siswa terhadap tes tersebut dapat mendeskripsikan sejauh mana kemampuan berinkuiri yang dimiliki siswa. Sedangkan instrumen pendukung berupa pedoman wawancara dan studi dokumentasi, untuk mendukung penjelasan terhadap temuan penelitian yang diperoleh tentang kemampuan berinkuiri siswa SMA pada topik pengaruh perubahan suhu terhadap sistem kesetimbangan kimia

\section{Hasil dan Pembahasan}

Jawaban siswa pada tes pilihan ganda yang dilakukan diolah dengan mengkonversikan jumlah jawaban benar dan jumlah siswa seluruhnya ke dalam bentuk persentase. Berdasarkan pengolahan data yang dilakukan, maka diperoleh sebaran persentase kemampuan berinkuiri siswa SMA dalam tiap aspek inkuirinya ditinjau dari setiap sekolah dan persentase rata-ratanya yang disajikan dalam tabel 1 . berikut. 
Tabel 1. Sebaran Persentase Kemampuan Berinkuiri Siswa SMA

\begin{tabular}{|c|l|c|c|c|c|c|c|}
\hline \multirow{2}{*}{$\begin{array}{c}\text { N } \\
\text { o }\end{array}$} & \multicolumn{1}{|c|}{ Aspek Berinkuiri } & \multicolumn{5}{|c|}{ Persentase Siswa yang Menjawab Benar } & Persentase \\
\cline { 3 - 7 } & & SMA A & SMA B & SMA C & SMA D & SMA E & (\%) \\
\hline 1. & Mengajukan Pertanyaan & 57,89 & 90,24 & 71,11 & 71,43 & 56,52 & 69,34 \\
\hline 2. & Merumuskan Hipotesis & 34,21 & 70,75 & 51,11 & 73,81 & 58,70 & 58,02 \\
\hline 3. & Merancang Percobaan & 28,95 & 56,10 & 33,33 & 28,57 & 15,22 & 32,08 \\
\hline 4. & Mengumpulkan Data & 73,68 & 92,68 & 66,67 & 85,71 & 63,04 & 75,94 \\
\hline 5. & Interpretasi Data & 55,26 & 85,37 & 84,44 & 85,71 & 65,22 & 75,47 \\
\hline 6. & Menyimpulkan & 63,16 & 97,56 & 73,33 & 80,95 & 30,45 & 68,40 \\
\hline
\end{tabular}

Dari tabel 1. tersebut, terlihat adanya perolehan persentase yang bervariasi dari setiap aspek berinkuiri yang diteliti, baik yang diperoleh dari setiap sekolah maupun persentase rata-ratanya. Selanjutnya analisis terhadap kemampuan berinkuiri siswa untuk setiap aspek tersebut dapat dijelaskan sebagai berikut.

\subsection{Kemampuan Berinkuiri Siswa pada Aspek Mengajukan Pertanyaan}

Keterampilan inkuiri berkembang atas dasar kemampuan siswa dalam menemukan dan merumuskan pertanyaan-pertanyaan yang bersifat ilmiah dan dapat mengarahkannya pada kegiatan penyelidikan untuk memperoleh jawaban atas pertanyaannya.

Seperti terlihat pada tabel 1 . di atas, aspek mengajukan pertanyaan adalah aspek yang dikuasai oleh sebagian besar dari rata-rata subjek penelitian, seperti juga ditunjukkan oleh interpretasi persentase yang diperoleh dari SMA A, C, D dan E. Hal tersebut disebabkan sering dilatihkannya kemampuan berinkuiri siswa pada aspek mengajukan pertanyaan dalam pembelajarannya. Mengajarkan siswa untuk bertanya sangat bermanfaat bagi perkembangannya sebagai saintis karena bertanya dan memformulasikan pertanyaan dapat mengembangkan kemampuan memberi penjelasan yang dapat diuji kebenarannya, dan merupakan bagian penting dari berpikir ilmiah (Suyanti, 2010).

Sementara itu, hampir seluruh subjek penelitian SMA B memiliki kemampuan berinkuiri pada aspek mengajukan pertanyaan. Tingginya persentase yang diperoleh SMA B ini didukung juga dari pernyataan guru kimia di sekolah tersebut tentang pentingnya latihan berinkuiri yang diterapkan melalui proses pembelajaran. Hal tersebut diperoleh dari hasil analisis transkrip wawancara yang dilakukan, yaitu adanya kebiasaan guru mengajarkan kimia yang dimulai dari masalah sehingga menyebabkan hampir seluruh siswanya terbiasa mempunyai gagasan untuk mengajukan pertanyaan, meskipun pada pembelajarannya pertanyaan itu bisa saja datang dari pihak guru. Dengan demikian, adanya kebiasaan tersebut mendukung terhadap tingginya persentase yang diperoleh siswa SMA B pada aspek ini.

\subsection{Kemampuan Berinkuiri Siswa pada Aspek Merumuskan Hipotesis}

Aspek merumuskan hipotesis adalah aspek yang dikuasai oleh sebagian besar subjek penelitian secara keseluruhan. Adapun faktor pendukung yang menyebabkan aspek ini dimiliki oleh sebagian besar subjek penelitian, antara lain dapat dilihat dari buku teks pelajaran yang biasa mereka gunakan.

Pada buku teks pelajaran yang mereka gunakan tersebut, yaitu buku teks pelajaran dengan simbol $P, R$ dan $T$ terdapat soal-soal yang mengukur kemampuan berinkuri siswa pada aspek merumuskan hipotesis. Soal-soal tersebut menuntut siswa untuk mampu merumuskan hipotesis berdasarkan pada data yang ada dalam soal dan pengetahuan yang telah dimiliki sebelumnya, sehingga 
siswa dapat mencari jawaban yang paling tepat dari soal-soal tersebut. Hal itu sesuai dengan salah satu indikator berhipotesis yang dikemukakan oleh Harlen (Anwar, 2007), yaitu mengusulkan penjelasan yang konsisten terhadap fakta dan menggunakan pengetahuan awal dalam membuat penjelasan. Soal-soal di buku teks pelajaran yang mengukur kemampuan berinkuiri siswa pada aspek merumuskan hipotesis ini memiliki jumlah yang paling banyak bila dibandingkan dengan aspek inkuiri lainnya.

Akan tetapi, SMA A yang juga menggunakan buku teks pelajaran yang sama tidak menunjukkan hal serupa dengan keempat sekolah lainnya. Hampir separuh subjek penelitian saja yang memiliki kemampuan berinkuiri pada aspek merumuskan hipotesis ini. Setelah dilakukan analisis, hal tersebut disebabkan kurang dilatihkannya kemampuan berinkuiri siswa pada aspek merumuskan hipotesis ini dalam proses pembelajarannya. Hal itu didukung dari hasil wawancara dengan guru kimia di sekolah tersebut yang mengungkapkan bahwa materi kesetimbangan kimia bersifat abstrak yang sulit untuk diungkap, sehingga menyebabkan pembelajarannya lebih kepada penyampaian materi saja tanpa melatihkan kemampuan berinkuiri siswa pada aspek merumuskan hipotesis. Selain itu, guru kimia yang ada di SMA tersebut tidak memiliki dan menggunakan RPP materi kesetimbangan kimia dalam pembelajarannya. Padahal keberadaan dan penggunaan RPP itu sangat penting karena dapat memberikan kerangka dan arahan bagi guru untuk mengajar, juga dapat menggambarkan tujuan dan sasaran pembelajaran yang jelas diharapkan dimiliki siswa setelah pembelajaran tersebut. Oleh sebab itu, kemampuan berinkuiri siswa pada aspek merumuskan hipotesis ini kurang dilatihkan dalam pembelajarannya.

\subsection{Kemampuan Berinkuiri Siswa pada Aspek Merancang Percobaan}

Seperti terlihat pada tabel 1. di atas, aspek merancang percobaan adalah aspek yang dikuasai paling sedikit oleh rata-rata subjek penelitian secara keseluruhan. Ada beberapa hal yang menyebabkan rendahnya persentase yang diperoleh pada aspek ini. Seperti dalam proses pembelajaran, guru tidak melatihkan kemampuan merancang percobaan pada siswa.

Walaupun di beberapa sekolah materi kesetimbangan kimia termasuk topik pengaruh perubahan suhu terhadap sistem kesetimbangan kimia diajarkan melalui praktikum yaitu seperti terlihat dari RPP SMA $B$ dan D, akan tetapi tidak ada kegiatan siswa di dalamnya yang dapat melatih mereka melakukan beberapa karakteristik kemampuan merancang percobaan. Langkahlangkah dalam melakukan percobaan biasanya langsung berasal dari instruksi guru atau sudah ada dalam lembar kerja siswa. Tidak ada arahan guru kepada siswanya untuk merancang percobaan atau merancang variabel-variabel. Padahal kemampuan tersebut penting dikembangkan agar pola pikir siswa menjadi berkembang, dan selanjutnya diharapkan dapat diaplikasikan dalam menyelesaikan masalah yang ada dalam kehidupannya.

Selain itu, berdasarkan hasil analisis yang dilakukan terhadap soal-soal yang ada dalam pembelajaran (diperoleh dari soal-soal yang ada di RPP), buku teks pelajaran maupun soal Ujian Nasional, tidak ada satu soal pun yang dapat mengukur kemampuan berinkuiri siswa pada aspek merancang percobaan ini. Hal tersebut turut menjadi salah satu kemungkinan alasan sedikitnya subjek penelitian yang dapat menjawab benar soal tersebut.

Selanjutnya apabila diperhatikan lagi tabel 1 . di atas, terdapat variasi perolehan persentase aspek merancang percobaan dari tiap sekolah, bahkan persentase yang diperoleh subjek penelitian di SMA E menunjukkan sebagian kecil siswa saja yang dapat menjawab benar soal tersebut. Hal itu disebabkan karena kemampuan berinkuiri pada aspek merancang percobaan ini tidak dikembangkan atau tidak dilatihkan dalam proses pembelajaran. Hal tersebut diperkuat dengan tidak adanya dan tidak digunakannya RPP pada materi kesetimbangan kimia di 
sekolah tersebut. Selain itu, banyak juga siswa yang masih asing dengan istilah variabel, baik itu variabel bebas, variabel terikat maupun variabel kontrol.

\subsection{Kemampuan Berinkuiri Siswa pada Aspek Mengumpulkan Data}

Seperti terlihat pada tabel 1. di atas, aspek mengumpulkan data adalah aspek yang dikuasai paling banyak oleh rata-rata subjek penelitian secara keseluruhan. Hal tersebut terlihat dari perolehan persentase yang paling tinggi di antara aspek berinkuiri lainnya.

Tingginya perolehan persentase pada aspek mengumpulkan data ini disebabkan dalam proses pembelajarannya materi kesetimbangan kimia tersebut dilaksanakan menggunakan metode praktikum. Beberapa keuntungan menggunakan metode praktikum ini antara lain adalah siswa dapat mengembangkan keterampilan inkuiri (dalam hal ini aspek mengumpulkan data) dan dapat mengembangkan sikap ilmiah (Arifin, 2003). Adapun informasi mengenai penggunaan metode praktikum dalam pembelajarannya ini dapat terlihat dari kegiatan pembelajaran yang ada di RPP SMA B dan C, dimana siswa telah dibiasakan untuk melihat dan mengamati data apa saja yang dapat diamati, sehingga banyak dari subjek penelitian yang bisa menjawab dengan benar soal yang berhubungan dengan pengamatan (mengumpulkan data) tersebut. Bahkan, hampir seluruh subjek penelitian yang ada di SMA B dapat menjawab dengan benar soal pada aspek ini.

Selain itu, berdasarkan hasil wawancara maka tingginya persentase yang diperoleh SMA D juga disebabkan dalam pembelajarannya materi kesetimbangan kimia tersebut diajarkan menggunakan metode praktikum. Oleh sebab itu, dengan dibiasakannya latihan berinkuiri aspek mengumpulkan data dalam pembelajaran, maka akan mempermudah siswa dalam mengembangkan kemampuan berinkuiri pada aspek tersebut.

\subsection{Kemampuan Berinkuiri Siswa pada Aspek Interpretasi Data}

Seperti terlihat pada tabel 1. di atas, perolehan persentase rata-rata yang ditunjukkan pada aspek interpretasi data ini tidak berbeda jauh dengan perolehan persentase pada aspek mengumpulkan data. Dengan demikian, dapat juga dikatakan aspek ini merupakan aspek yang dikuasai paling banyak oleh subjek penelitian secara keseluruhan setelah aspek mengumpulkan data.

Salah satu faktor pendukung tingginya persentase yang diperoleh pada aspek interpretasi data ini adalah adanya latihan inkuiri pada aspek tersebut yang diberikan guru dalam proses pembelajaran. Siswa terbiasa melihat data yang disajikan dalam bentuk tabel/charta atau bentuk lainnya untuk kemudian ditafsirkan sesuai dengan kemampuannya. Subjek penelitian mampu membaca pola yang ada dalam tabel yang disajikan, sehingga mereka mampu mendapatkan penafsiran yang tepat. Oleh sebab itu, interpretasi dari persentase yang diperoleh SMA B dan C menunjukkan bahwa hampir seluruh subjek penelitiannya memiliki kemampuan berinkuiri pada aspek tersebut.

\subsection{Kemampuan Berinkuiri Siswa pada Aspek Menyimpulkan}

Seperti terlihat pada tabel 1. di atas, sebagian besar dari keseluruhan subjek penelitian memiliki kemampuan berinkuiri pada aspek menyimpulkan. Adanya soal di buku teks pelajaran yang memiliki karakteristik sesuai dengan aspek menyimpulkan yaitu pada buku teks pelajaran $P$, menjadi salah satu faktor pendukung terhadap hasil tes yang diperoleh setiap sekolah pada aspek ini.

Selain itu, adanya sebagian besar subjek penelitian dari SMA C yang memiliki kemampuan berinkuiri pada aspek ini disebabkan juga dari kegiatan pembelajarannya. Setelah dilakukan analisis terhadap RPP yang digunakan, maka dalam kegiatan pembelajaran di SMA C tersebut terdapat kegiatan guru yang mengarahkan 
siswa untuk membuat rangkuman. Oleh sebab itu, siswa telah dibiasakan dan dilatih untuk dapat membuat kesimpulan berdasarkan data yang terkumpul dan relevan. Begitu pula halnya dengan subjek penelitian yang berasal dari SMA B, dimana hampir seluruhnya memiliki kemampuan berinkuiri pada aspek ini yang disebabkan telah dibiasakannya latihan berinkuiri pada aspek tersebut dalam pembelajarannya. Hal itu terlihat dari LKS pada materi kesetimbangan kimia yang digunakan dalam proses pembelajarannya.

Namun demikian, hampir separuhnya saja subjek penelitian SMA E yang dapat menjawab soal pada aspek menyimpulkan ini dengan benar. Hal itu disebabkan kurang dilatihkannya aspek tersebut dalam kegiatan pembelajarannya. Tidak adanya RPP yang dimiliki dan digunakan oleh guru SMA E pada materi kesetimbangan kimia menjadi alasan bagi peneliti bahwa kemungkinan guru tersebut kurang memiliki persiapan dalam menyusun kegiatan/skenario pembelajaran yang dilakukan, sehingga kegiatan siswa untuk menyimpulkan atau membuat suatu kesimpulan tidak dilatihkan.

\section{Kesimpulan}

Berdasarkan hasil penelitian mengenai profil kemampuan berinkuiri siswa SMA pada topik pengaruh perubahan suhu terhadap sistem kesetimbangan kimia, maka dapat diambil kesimpulan bahwa kemampuan berinkuiri siswa SMA pada topik pengaruh perubahan suhu terhadap sistem kesetimbangan kimia menunjukkan hasil yang bervariasi.

Adapun profil kemampuan berinkuiri siswa secara keseluruhan untuk setiap aspek inkuiri yang diteliti dapat disimpulkan sebagai berikut:

1. Sebagian besar siswa $(69,34 \%)$ memiliki kemampuan berinkuiri pada aspek mengajukan pertanyaan.

2. Sebagian besar siswa $(58,02 \%)$ memiliki kemampuan berinkuiri pada aspek merumuskan hipotesis.
3. Hampir separuh siswa $(32,08 \%)$ memiliki kemampuan berinkuiri pada aspek merancang percobaan.

4. Sebagian besar siswa $(75,94 \%)$ memiliki kemampuan berinkuiri pada aspek mengumpulkan data.

5. Sebagian besar siswa $(75,47 \%)$ memiliki kemampuan berinkuiri pada aspek interpretasi data.

6. Sebagian besar siswa $(68,40 \%)$ memiliki kemampuan berinkuiri pada aspek menyimpulkan.

\section{Daftar Pustaka}

Akhyani, A. (2008). Model Pembelajaran Kesetimbagan Kimia Berbasis Inkuiri Laboratorium untuk Meningkatkan Penguasaan Konsep dan Keterampilan Kritis Siswa SMA. Tesis, Sekolah Pascasarjana: Universitas Pendidikan Indonesia.

Alberta. (2004). Learning and Teaching Resources Branch. Focus on inquiry: a teacher's guide to implementing inquiry-based learning. Canada: Minister of Learning.

Amien, M. (1987). Mengajarkan Ilmu Pengetahuan Alam (IPA) dengan Mengguanakan Metode "Discovery" dan "Inquiry" Bagian I. Jakarta: Departemen Pendidikan dan Kebudayaan Direktorat Jenderal Pendidikan Tinggi.

Anwar, R. (2007). Profil Kinerja Keterampilan Proses Sains Siswa SMA dalam Kegiatan Pembelajaran di Luar Kelas (Field Trip) pada Konsep Keanekaragaman Hewan Vertebrata. Skripsi, FPMIPA: Universitas Pendidikan Indonesia.

Arifin, M. dkk. (2003). Strategi Belajar Mengajar Kimia. Bandung: Jurusan Pendidikan Kimia FPMIPA UPI.

Badan Standar Nasional Pendidikan. (2006). Peraturan Menteri Pendidikan Nasional Republik Indonesia Nomor 22 Tahun 2006 tentang Standar Isi untuk Satuan 
Pendidikan Dasar dan Menengah. Jakarta: Depdiknas.

Exline. (2004). Workshop: Inquiry-Based Learning [Online]. Tersedia: http://www.thirteen.org/edoline/concep t2class/inquiry/index-sub2.html. Januari 2009].

Hamdu, G. (2007). Pembelajaran Hidrolisis Garam dengan Model Inkuiri untuk Mengembangkan Kemampuan Dasar Bekerja Ilmiah Siswa Kelas XI. Tesis, Sekolah Pascasarjana: Universitas Pendidikan Indonesia.

Hidayat, W. (2004). Model Pembelajaran Inkuiri Terbimbing dengan Kegiatan Laboratorium pada Pokok Bahasan Koloid. Skripsi, FPMIPA: Universitas Pendidikan Indonesia.

Joyce, et al. (2000). Models of Teaching. Sixth Edition. New Jersey: Prentice-Hall Inc.

Lugina, W. (2005). Analisis Kesulitan Siswa SMA Kelas 2 Pada Topik Kesetimbangan Kimia melalui Skema Pemecahan Masalah. Skripsi, FPMIPA: Universitas Pendidikan Indonesia.

Rustaman, N. (2004). Mengefektifkan Pembelajaran Sains dan Animasinya untuk Pengembangan Kemampuan Dasar Bekerja Ilmiah dengan Berbagai Metode. Laporan penelitian hibah penelitian Tim Pasca Sarjana, Bandung: Program Pasca Sarjana UPI

Sidharta, A. (2005). Model Pembelajaran Asam Basa Berbasis Inkuiri Laboratorium sebagai Wahana Pendidikan Sains Siswa SMP. Tesis, Sekolah Pascasarjana: Universitas Pendidikan Indonesia.

Sukmadinata, N.S. (2007). Metode Penelitian Pendidikan. Bandung: PT. Remaja Rosda Karya.

Susanti, S. (2005). Penerapan Pembelajaran Inkuiri untuk Meningkatkan Hasil Belajar Siswa SMA Kelas XI pada Materi
Pokok Hidrolisis Garam. Skripsi, FPMIPA: Universitas Pendidikan Indonesia.

Suyanti, R. D. (2010). Strategi Pembelajaran Kimia. Yogyakarta: Graha Ilmu.

Trianto. (2009). Mendesain Model Pembelajaran Inovatif-Progresif. Jakarta: Kencana Prenada Media Group. 